No 4078

Studia nad Autorytaryzmem i Totalitaryzmem 43, nr 4 Wrocław 2021

https://doi.org/10.19195/2300-7249.43.4.42

\author{
PIOTR RODZIEWICZ \\ ORCID: 0000-0002-1666-4202 \\ Uniwersytet Wrocławski \\ piotr.rodziewicz@uwr.edu.pl
}

\title{
Wpływ braku uznania rządu państwa totalitarnego i autorytarnego na zdolność sądową tego państwa w świetle koncepcji brytyjsko-amerykańskich
}

Słowa kluczowe: uznanie rządu, zdolność sądowa, państwo obce, zagraniczne osoby prawne.

\author{
IMPACT OF GOVERNMENT NON-RECOGNITION OF A TOTALITARIAN AND \\ AN AUTHORITARIAN STATE ON THE LOCUS STANDI OF THIS STATE AND ITS STATE \\ LEGAL PERSONS IN THE LIGHT OF ANGLO-AMERICAN CONCEPTS
}

\begin{abstract}
Although government recognition is a legal concept of public international law, it interacts with other branches of law, including private international law and international civil procedure. According to the jurisprudence of British and American courts, unrecognized governments do not possess locus standi in civil proceedings in regard to matters which fall within the state dominium. In the mentioned jurisprudence, a doctrine has been formulated according to which judges are bound by the position of their state executive bodies in regard to foreign state and government recognition, which has direct influence on the locus standi of foreign states in the courts of Britain and the United States. The aim of this paper is to present the above rulings, as well as to analyze whether there are grounds for accepting the doctrine which follows from them in Polish civil litigation.
\end{abstract}

Keywords: government recognition, locus standi, foreign state, foreign state legal person. 


\section{Zagadnienia wstępne}

Prawne konsekwencje uznania rządu zasadniczo stanowią przedmiot zainteresowania doktryny prawa międzynarodowego publicznego ${ }^{1}$. Zauważyć jednak należy, że wskazana problematyka w istotny sposób może oddziaływać na stosunki prawne i sytuacje życiowe stanowiące przedmiot regulacji norm prawnych z zakresu innych gałęzi niż prawo międzynarodowe publiczne ${ }^{2}$. W szczególności opisane oddziaływanie jest dostrzegalne na płaszczyźnie prawa prywatnego międzynarodowego oraz międzynarodowego postępowania cywilnego ${ }^{3}$. Niezależnie od tego omawiana problematyka ma również wymiar praktyczny, albowiem aktualnie w społeczności międzynarodowej funkcjonują zarówno państwa, których uznanie jest kwestionowane, jak i rządy nieuznawane, a państwa te realizują funkcje $\mathrm{z}$ zakresu dominium ${ }^{4}$, uczestnicząc $\mathrm{w}$ obrocie prywatnoprawnym $\mathrm{z}$ elementem obcym.

Przedmiotem niniejszego artykułu jest przedstawienie, czy i w jakim zakresie koncepcje sformułowane w orzecznictwie sądów brytyjskich oraz amerykańskich odnoszące się do wpływu uznania rządu państwa na możliwość występowania tego państwa w ramach postępowań cywilnych przed sądami obcymi pozostają obecnie aktualne. Ponadto przedstawiona zostanie analiza dotycząca możliwości wykorzystania omówionych koncepcji z perspektywy polskiego systemu prawnego.

\section{Uznanie rządu}

Uznanie rządu wymaga wyraźnego odróżnienia od instytucji uznania państwa w prawie międzynarodowym publicznym ${ }^{5}$. Problem ten ujawnia się w sytuacji, w której dochodzi do zmian w strukturze państwa w sposób niekonstytucyjny $^{6}$. W prawie międzynarodowym publicznym brakuje jednej uniwersalnej definicji uznania. Przyjmuje się jednak, że jest to stwierdzenie przez państwo, że

1 Zob. S. Talmon, Recognition of Governments in International Law with Particular Reference to Governments in Exile, Oxford 1998, s. 30 n.

2 Zob. E.F. Kobey, International Law - Recognition and Non-Recognition of Foreign Governments, „Marquette Law Review” 34, 1951, nr 282, http://scholarship.law.marquette.edu/mulr/ vol34/iss4/6 (dostęp: 20.04.2021).

3 J.R. Stevenson, Effect of Recognition on the Application of Private International Law Norms, „Columbia Law Review” 51, 1951, nr 6, s. 710.

${ }^{4}$ Zob. A. Szumański, Renegocjacja umów w międzynarodowym obrocie gospodarczym: studium prawnoporównawcze, Kraków 1994, s. 71 n.

5 W. Czapliński, A. Wyrozumska, Prawo międzynarodowe publiczne. Zagadnienia systemowe, Warszawa 2004, s. 303.

${ }^{6}$ Ibidem. 
przedmiot uznania istnieje i powinien być traktowany w płaszczyźnie prawa międzynarodowego ${ }^{7}$. Zgodnie $\mathrm{z}$ innym poglądem uznaniem jest stwierdzenie przez podmiot udzielający uznania istnienia pewnych faktów i gotowość respektowania związanych z tym skutków prawnych ${ }^{8}$. Podobnie jak w przypadku uznania państwa, tak i w odniesieniu do uznania rządu wyróżnia się uznanie de facto oraz uznanie de iure. Jak wskazano w literaturze, to pierwsze ma miejsce, gdy podmiot uznawany spełnia warunek efektywności, ale nie uzyskał wystarczającej stabilności lub nie spełnia wszystkich warunków niezbędnych do pełnego uznania ${ }^{9}$. Niezależnie od powyższego podkreślić należy, że z punktu widzenia prawa międzynarodowego publicznego legitymizacja rządu nie jest jednak konieczna, co znalazło wyraz w braku powszechnej akceptacji doktryny Tobara ${ }^{10}$. Podstawowym wymogiem, jaki rząd musi natomiast spełniać, jest sprawowanie efektywnej władzy na terytorium danego państwa ${ }^{11}$. Powszechnie przyjmuje się, że rządem nieuznawanym jest pozbawiony uznania politycznego w jakiejkolwiek postaci, to jest — de iure lub de facto, ze strony organów władzy wykonawczej innego państwa $^{12}$. Mając powyższe na uwadze, z punktu widzenia przedmiotu niniejszego opracowania istotne pozostaje, czy rząd danego państwa jest uznawany przez inne kraje, natomiast znaczenia nie ma, czy uznanie ma charakter de iure czy też de facto. Podobnie wskazuje się w nauce prawa międzynarodowego publicznego, podkreślając, że podział charakteru uznania ma jedynie wymiar teoretyczny, natomiast pozbawiony jest on skutków z praktycznego punktu widzenia ${ }^{13}$.

7 R. Bierzanek, J. Symonides, Prawo międzynarodowe publiczne, Warszawa 2005, s. 140.

8 W. Góralczyk, S. Sawicki, op. cit., Warszawa 2004, s. 148.

9 M. Daniluk, Problem uznania rządu w prawie międzynarodowym na przykładzie uznania libijskiej Narodowej Rady Tymczasowej, „Studia Iuridica Lublinensia” 20, 2013, s. 123 z przywołaną tam literaturą, to jest L. Oppenheim, H. Lauterpacht, International Law: A Treatise, t. 1, London 1955, s. 135.

10 Zob. A. Zaćmiński, Uznanie i przeniesienie uznania rządu w stosunkach międzynarodowych - casus Polski 1939 i 1945 rok, [w:] Historia, polityka, stosunki międzynarodowe, red. A. Zaćmiński, Bydgoszcz 2010, s. 76 n.; C. Stansifer, Application of the Tobar Doctrine to Central America, „The Americas” 23, 1967, nr 3, s. 253 n., https:/www.jstor.org/stable/980469 (dostęp: 20.04.2021).

11 Zob. H. Lauterpacht, Recognition of Governments: I, „Columbia Law Review” 45, 1945 , nr 6, s. 840; W. Czapliński, A. Wyrozumska, op. cit., s. 303.

12 N.D. Houghton, The Position of Unrecognized Governments Before the Courts of Foreign States, ,Indiana Law Journal” 4, 1929, nr 8, s. 519, http://www.repository.law.indiana.edu/ilj/vol4/ iss8/1 (dostęp: 20.04.2021).

13 Zob. J. Symonides, Kryteria uznania państwa i rzadu $w$ teorii i praktyce międzynarodowej, „Zeszyty Naukowe Uniwersytetu Mikołaja Kopernika w Toruniu. Nauki Humanistyczno-Społeczne" 1969, z. 36, s. 37. 


\section{Wpływ braku uznania rządu na zdolność sądową państwa}

Zasadniczo państwa obce posiadają zdolność sądową przed sądami angielskimi (locus standi in iudicio) $)^{14}$, jak i sądami amerykańskimi ${ }^{15}$. W odniesieniu do państw nieuznanych oraz nieuznanych rządów zarówno w Wielkiej Brytanii, jak i Stanach Zjednoczonych wykształciła się doktryna związania sędziego aktem władzy wykonawczej w przedmiocie uznania państwa lub rządu. Doktryna ta sięga swymi korzeniami XVIII wieku. Przed przejściem do szczegółowej analizy zarówno samej doktryny, jak i orzeczeń sądów, w ramach których doszło do jej ukształtowania, podkreślenia wymaga to, że znajduje ona zastosowanie nie tylko do rządów państw totalitarnych i autorytarnych ${ }^{16}$, ale również w odniesieniu do każdego innego kraju i rządu, który nie został uznany przez organy władzy wykonawczej. Co jednak charakterystyczne, kilka orzeczeń w swym stanie faktycznym odnosiło się do nieuznawanego przez Stany Zjednoczone ${ }^{17}$ rządu Rosji Sowieckiej, a więc państwa totalitarnego.

W sprawie The Penz oraz The Tobolsk ${ }^{18}$ Sąd Okręgowy Stanów Zjednoczonych dla wschodniego okręgu Nowego Jorku orzekł, że rząd Rosji Sowieckiej, który nie został uznany przez Stany Zjednoczone, nie może wystąpić z powództwem przed sądami amerykańskimi. Podobna konkluzja została wyrażona w sprawie z powództwa Rosji Sowieckiej przeciwko Cibrario ${ }^{19}$. Sąd amerykański uznał, że państwo obce może pozywać przed sądami amerykańskimi, jeżeli zostało uznane przez amerykański rząd ${ }^{20}$. Analiza przedstawionych orzeczeń prowadzi do wniosku, że uznanie rządu państwa obcego stanowi warunek uzyskania zdolności sądowej przed sądami amerykańskimi. Jednocześnie orzecznictwo to wskazuje, że w zakresie uznania obcego rządu wiążące jest stanowisko organów władzy wykonawczej.

Konkluzje wynikające z przytoczonych orzeczeń sądów amerykańskich są zbieżne z poglądami wyrażonymi w orzecznictwie sądów angielskich. Reprezentatywne w tym zakresie jest szczególnie orzeczenie w sprawie The City of Berne

14 Zob. G. Marston, The Personality of the Foreign State in English Law, „The Cambridge Law Journal" 56, 1997, nr 2, s. 374, http://www.jstor.org/stable/4508347 (dostęp: 20.04.2021).

15 Zob. E. Dickinson, Recent Recognition Cases, „The American Journal of International Law” 19, 1925, nr 2, s. 264.

16 O pojęciu państwa totalitarnego oraz autorytarnego zob. więcej M. Bankowicz, Autorytaryzm i totalitaryzm: analiza porównawcza, [w:] Totalitaryzmy XX wieku: idee, instytucje, interpretacje, red. W. Kozub-Ciembroniewicz, H. Kowalska-Stus, B. Szlachta, M. Kiwior-Filo, Kraków 2010, s. 26 n.

17 E. Dickinson, op. cit., s. 263.

18 The Penza, 277 Fed. 91.

19 Russian Soc. Fed. Soviet Rep. v. Cibrario, 235 N.Y. 255, 139 N.E. 259 (1923).

20 Ibidem. 
in Switzerland v. The Bank of England ${ }^{21}$. W orzeczeniu tym przyjęto, że obcy rząd musi zostać uznany przez rząd brytyjski, zanim będzie mógł wystąpić z powództwem. Sąd brytyjski podobnie jak sądy amerykańskie przyjął przy tym, że sędzia w zakresie uznania obcego państwa lub rządu jest związany stanowiskiem organów władzy wykonawczej, jeśli organy te nie uznają obcego państwa lub rządu, nie jest ono podmiotem prawa międzynarodowego, a w konsekwencji nie ma możliwości występowania $\mathrm{w}$ charakterze strony $\mathrm{w}$ postępowaniu sądowym. Podstawą omawianej doktryny jest założenie, że wyłączna kompetencja do prowadzenia polityki zagranicznej przysługuje organom władzy wykonawczej ${ }^{22}$.

\section{Brak uznania państwa a zdolność sądowa państwa obcego z perspektywy polskiego systemu prawnego}

Zdolność sądowa cudzoziemców oraz zagranicznych osób prawnych, a za taką powinno być uznane państwo obce $\mathrm{z}$ perspektywy polskiego prawa procesowego, podlega ocenie przez pryzmat prawa właściwego wskazanego za pomocą norm kolizyjnych prawa prywatnego międzynarodowego wyznaczających statut personalny, które znajdują zastosowanie w związku z art. 1117 § 1 k.p.c. Zgodnie z przywołanym przepisem zdolność sądową zagranicznych osób prawnych i jednostek organizacyjnych niebędących osobami prawnymi określa się według prawa właściwego dla ich zdolności prawnej. Prawo właściwe dla zdolności prawnej jest wskazywane w odniesieniu do osób prawnych w oparciu o art. 17 p.p.m. Mając powyższe na uwadze, ocena zdolności sądowej państwa obcego zasadniczo powinna być dokonywana na podstawie prawa tego państwa. Jeśli państwo obce zgodnie $\mathrm{z}$ prawem $\mathrm{w}$ nim obowiązującym posiada zdolność sądową, na podstawie art. $1117 \S 1$ k.p.c. w zw. $z$ art. 17 p.p.m. prawo to będzie właściwe dla oceny zdolności sądowej państwa obcego przed sądami polskimi ${ }^{23}$. W orzecznictwie przyjmuje się, że państwa obce oraz zależne od niego jednostki organizacyjne posiadają zdolność sądową z odwołaniem do przywołanych wyżej przepisów ${ }^{24}$, oczywiście kwestią wtórną pozostaje, czy i w jakim zakresie objęte są one immunitetem w postępowaniu cywilnym ${ }^{25}$. W orzecznictwie nie ma jednoznacznych poglądów wskazujących na to, czy brak uznania rządu państwa obcego przez władze polskie ma wpływ na zdolność sądową państwa obcego przed sądami polskimi. Uzasadnione jest jednak odwołanie się do poglądu dotyczącego

21 The City of Berne in Switzerland v. The Bank of England, 9 Ves. 347.

22 M. Grzegorczyk, Uznanie państwa lub rządu jako przesłanka stosowania prawa obcego, „Zeszyty Naukowe Uniwersytetu Jagiellońskiego. Prace Prawnicze” 1968, z. 37, s. 84.

23 Zob. P. Grzegorczyk, Immunitet państwa w postępowaniu cywilnym, Warszawa 2010, s. 494 n.

24 Postanowienie SN z dnia 25 maja 2007 roku, I CSK 6/07, SIP LEX nr 315565.

25 Uchwała SN z dnia 16 września 1990 roku, sygn. III PZP 9/90, OSNC 1991/2-3/17. 
możliwości stosowania przez sąd jako właściwego prawa państwa nieuznanego. Zgodnie z poglądem wyrażonym przez M. Grzegorczyka koncepcje akceptowane w państwach kontynentalnej Europy oparte na zasadzie realizmu odrzucają uznanie państwa i rządu w kontekście warunku stosowania prawa obcego jako właściwego ${ }^{26}$. Przedstawiony pogląd jest również uzasadniony w odniesieniu do możliwości występowania przez państwo obce w postepowaniu cywilnym. Zauważyć bowiem należy, że w obrocie prywatnoprawnym działa wówczas w sferze dominium, a nie imperium ${ }^{27}$. $\mathrm{Z}$ tej perspektywy uznanie rządu państwa obcego jest irrelewantne $\mathrm{z}$ punktu widzenia możliwości występowania przez to państwo w charakterze strony lub uczestnika postępowania. Jednocześnie podkreślić należy, że pośrednio z postanowienia SN z dnia 25 maja 2007 roku (sygn. I CSK 6/07) można wywieść, że zdolność sądowa państwa nie jest uzależniona od jego uznania, na co trafnie zwrócił uwagę P. Grzegorczyk ${ }^{28}$.

\section{Podsumowanie}

Brak uznania rządu państwa, w tym rządu państwa totalitarnego i autorytarnego, w świetle koncepcji prezentowanych w orzecznictwie brytyjsko-amerykańskim powoduje brak zdolności sądowej takiego państwa. W konsekwencji podmioty te nie mogą zgodnie z przedstawionym orzecznictwem występować w postepowaniu cywilnym. Powyższe jest elementem szeroko ujmowanej doktryny związania sędziego stanowiskiem władzy wykonawczej państwa, w którym orzeka w zakresie uznania państwa obcego oraz rządu, akceptowanej zarówno w Wielkiej Brytanii, jak i Stanach Zjednoczonych. Podstawą tej doktryny jest założenie, że wyłączna kompetencja do prowadzenia polityki zagranicznej przysługuje organom władzy wykonawczej ${ }^{29}$. Brak jest podstaw normatywnych umożliwiających recepcje przedstawionej doktryny w polskim procesie cywilnym. Ponadto uznać należy, że zasada realizmu odrzucająca uznanie państwa i rządu w kontekście warunku stosowania prawa obcego jako właściwego swym zakresem obejmuje również zdolność sądową państw obcych.

${ }^{26}$ M. Grzegorczyk, op. cit., s. 99.

27 Zob. A. Doliwa, Dychotomiczny charakter podmiotowości prawnej państwa (dominium i imperium), „Studia Prawnicze” 2002, z. 3, s. 36 n.

28 P. Grzegorczyk, op. cit., s. 494 n.

29 M. Grzegorczyk, op. cit., s. 84. 


\section{Bibliografia}

Bankowicz M., Autorytaryzm i totalitaryzm: analiza porównawcza, [w:] Totalitaryzmy XX wieku: idee, instytucje, interpretacje, red. W. Kozub-Ciembroniewicz, H. Kowalska-Stus, B. Szlachta, M. Kiwior-Filo, Kraków 2010.

Bierzanek R., Symonides J., Prawo międzynarodowe publiczne, Warszawa 2005.

Czapliński W., Wyrozumska A., Prawo międzynarodowe publiczne. Zagadnienia systemowe, Warszawa 2004.

Daniluk M., Problem uznania rządu w prawie międzynarodowym na przykładzie uznania libijskiej Narodowej Rady Tymczasowej, „Studia Iuridica Lublinensia” 20, 2013.

Dickinson E., Recent Recognition Cases, „The American Journal of International Law” 19, 1925, nr 2.

Doliwa A., Dychotomiczny charakter podmiotowości prawnej państwa (dominium i imperium), „Studia Prawnicze” 2002, z. 3.

Góralczyk W., Sawicki S., Prawo międzynarodowe publiczne w zarysie, Warszawa 2004.

Grzegorczyk M., Uznanie państwa lub rządu jako przestanka stosowania prawa obcego, „Zeszyty Naukowe Uniwersytetu Jagiellońskiego. Prace Prawnicze" 1968, z. 37.

Grzegorczyk P., Immunitet państwa w postępowaniu cywilnym, Warszawa 2010.

Houghton N.D., The Position of Unrecognized Governments Before the Courts of Foreign States, „Indiana Law Journal” 4, 1929, nr 8.

Kobey E.F., International Law - Recognition and Non-Recognition of Foreign Governments, „Marquette Law Review” 34, 1951, nr 282.

Lauterpacht H., Recognition of Governments: I, „Columbia Law Review” 45, 1945, nr 6.

Marston G., The Personality of the Foreign State in English Law, „The Cambridge Law Journal” 56, $1997, \mathrm{nr} 2$.

Stansifer C., Application of the Tobar Doctrine to Central America, „The Americas” 23, 1967, nr 3.

Stevenson J.R., Effect of Recognition on the Application of Private International Law Norms, „Columbia Law Review" 51, 1951, nr 6.

Symonides J., Kryteria uznania państwa $i$ rządu w teorii i praktyce międzynarodowej, „Zeszyty Naukowe Uniwersytetu Mikołaja Kopernika w Toruniu. Nauki Humanistyczno-Społeczne” 1969, z. 36.

Szumański A., Renegocjacja umów w międzynarodowym obrocie gospodarczym: studium prawnoporównawcze, Kraków 1994.

Talmon S., Recognition of Governments in International Law with Particular Reference to Governments in Exile, Oxford 1998.

Zaćmiński A., Uznanie i przeniesienie uznania rządu w stosunkach międzynarodowych - casus Polski 1939 i 1945 rok, [w:] Historia, polityka, stosunki międzynarodowe, red. A. Zaćmiński, Bydgoszcz 2010. 